\title{
Boerhaavia diffusa L. attenuates angiotensin II-induced hypertrophy in H9c2 cardiac myoblast cells via modulating oxidative stress and down-regulating NF-к $\beta$ and transforming growth factor $\beta 1$
}

\author{
A. Prathapan ${ }^{1}$, V. P. Vineetha ${ }^{1}$, P. A. Abhilash ${ }^{2}$ and K. G. Raghu ${ }^{1 *}$ \\ ${ }^{1}$ Agroprocessing and Natural Products Division, Council of Scientific and Industrial Research-National Institute for \\ Interdisciplinary Science and Technology (CSIR-NIIST), Pappanamcode, Trivandrum 695 019, Kerala, India \\ ${ }^{2}$ Department of Biochemistry, University of Kerala, Kariavattom Campus, Trivandrum 695 581, Kerala, India \\ (Submitted 17 July 2012 - Final revision received 29 January 2013 - Accepted 29 January 2013 - First published online 16 April 2013 )
}

\section{Abstract}

The present study evaluated the antihypertrophic potential of the ethanolic extract of Boerhaavia diffusa (BDE), a well-known edible cardiotonic plant reported in Ayurveda against angiotensin II-induced hypertrophy in H9c2 cardiac myoblast cells. Markers of hypertrophy such as cell size, protein content and the concentrations of atrial natriuretic peptide (ANP) and B-type natriuretic peptide (BNP) were analysed for the confirmation of hypertrophy induction. Angiotensin II (100 nm) caused an increase in cell volume (69.26 (SD 1.21)\%), protein content (48.48 (SD 1.64)\%), ANP (81.90 (SD 1.22)\%) and BNP (108.57 (SD 1.47)\%). BDE treatment significantly reduced cell volume, protein content and the concentrations of ANP and BNP $(P \leq 0.05)$ in H9c2 cells. The activity of various antioxidant enzymes and the concentration of reduced glutathione, which was lowered due to hypertrophy, were increased in BDE-treated cells. The BDE treatment also reduced intracellular reactive oxygen species generation, lipid peroxidation and protein carbonyls in cells. In addition, the expression patterns of NF-к $\beta$ and transforming growth factor $\beta 1$ were found to be increased during hypertrophy, and their expressions were reduced on BDE treatment. In vitro chemical assays showed that BDE inhibits angiotensin-converting enzyme and xanthine oxidase in a dose-dependent manner with an estimated $50 \%$ effective concentration ( $\mathrm{EC}_{50}$ ) value of $166 \cdot 12$ (SD $\left.2 \cdot 42\right)$ and $60 \cdot 05$ (sD 1.54$) \mu \mathrm{g} / \mathrm{ml}$, respectively. The overall results clearly indicate the therapeutic potential of $B$. diffusa against cardiac hypertrophy, in addition to its nutritional qualities.

Key words: Boerhaavia diffusa: Cardiac hypertrophy: Atrial natriuretic peptide: Xanthine oxidase: Reactive oxygen species: Transcription factors

Cardiac hypertrophy is one of the major predictors of progressive heart disease and an independent risk factor for cardiac morbidity and mortality ${ }^{(1)}$. It is the enlargement of the heart with an increase in the volume of cardiac cells, and prolonged hypertrophic status has been reported to be associated with the decompensation of heart function, the development of heart failure and sudden death in humans ${ }^{(2)}$. One of the major signal transduction mechanisms leading to the development of cardiac hypertrophy is the overproduction of reactive oxygen species (ROS) $)^{(3)}$. An increase in ROS production both in vitro and in vivo is implicated in the development of cardiac hypertrophy and its pathophysiology ${ }^{(4)}$. Excessive ROS generation triggers cell dysfunction, lipid peroxidation and DNA mutagenesis, and can lead to irreversible cell damage or death ${ }^{(5)}$. Therapeutic intervention via suppression of oxidative stress and/or an increase in endogenous antioxidant enzymes may attenuate cardiac hypertrophy and associated complications. Recent studies have shown that treatment with antioxidants inhibits the hypertrophic response of cardiac myocytes ${ }^{(6)}$.

Functional foods and nutraceuticals are becoming a part of everyday life and play an important role in maintaining human health. Plant foods can be considered as functional foods since they are all rich in phytochemicals or nutraceuticals, and they have been claimed to possess physiological benefits or provide protection against chronic diseases beyond their basic nutritional functions ${ }^{(7)}$. Epidemiological evidence suggests that diets rich in plant foods are associated with a

Abbreviations: ACE, angiotensin-converting enzyme; ANP, atrial natriuretic peptide; BDE, Boerhaavia diffusa extract; BNP, B-type natriuretic peptide; GSH, reduced glutathione; LDH, lactate dehydrogenase; ROS, reactive oxygen species; TBARS, thiobarbituric acid-reactive substances; TGF- $\beta 1$, transforming growth factor $\beta 1$; TPC, total phenolic content; $\mathrm{XO}$, xanthine oxidase.

*Corresponding author: Dr K. G. Raghu, fax +91 471 2491712/2491585, email raghukgopal2009@gmail.com 
lower incidence of CVD, diabetes, cancer and other degenerative diseases ${ }^{(8)}$. It has been proposed that a higher dietary intake rich in vegetables and fruits or antioxidant phytochemicals is associated with a lower risk of CVD and mortality $^{(9)}$.

Boerhaavia diffusa L. from the family Nyctaginaceae is an important indigenous medicinal plant widely used in Ayurveda. It is commonly known as punarnava, has a long history of use by indigenous and tribal people ${ }^{(10)}$ and is used against epilepsy in Nigerian folk medicine ${ }^{(11,12)}$. B. diffusa has also been widely used for the treatment of dyspepsia, jaundice, enlargement of spleen, abdominal pain and fibrinolytic, and as an anti-stress agent ${ }^{(11)}$. The plant has been reported to possess cardiotonic and antihypertensive potential ${ }^{(13,14)}$. Pharmacological studies have demonstrated that punarnava possesses antidiabetic $^{(15)}$, immunomodulatory ${ }^{(16)}$, anticonvulsant, hepatoprotective, antibacterial, antiproliferative and anti-oestrogenic activities $^{(10,17)}$. The plant has been well demonstrated to have antimitotic activity in in vitro systems and inhibits the growth of several monocytic, lymphoblastoid, fibroblast and erythroleukaemic cell lines of mouse and human origin $^{(17)}$. The plant possesses antioxidant potential, and experimental studies have demonstrated that $B$. diffusa could be effective in the prevention and treatment of diseases in which oxidants or free radicals are implicated ${ }^{(12,18-21)}$. B. diffusa is not only used as a medicinal plant but also used as a green leafy vegetable due to its nutraceutical properties in most of the Asian countries ${ }^{(12)}$.

The present study aimed to evaluate whether $B$. diffus $a$ can ameliorate hypertrophy induced by angiotensin II in H9c2 cells, and its effects on oxidative stress and transcription factors such as NF-к $\beta$ and transforming growth factor $\beta 1$ (TGF- $\beta 1$ ).

\section{Materials and methods}

\section{Preparation of Boerhaavia diffusa extract}

B. diffusa was collected from the local areas of Thiruvananthapuram, India during the month of May, and identified and authenticated by Dr H. Biju, Taxonomist from the Jawaharlal Nehru Tropical Botanical Garden Research Institute, Palode, Thiruvananthapuram, Kerala. A voucher specimen was deposited in our herbarium for future reference (no. 01/05/2010 APNP/CSIR-NIIST). Extraction of the plant material was carried out according to the method described previously, with slight modifications ${ }^{(19)}$. Briefly, the fresh whole plants were air-dried and extracted with ethanol at ambient temperature $\left(27 \pm 1^{\circ} \mathrm{C}\right)$ under stirring for $6 \mathrm{~h}$, and the extraction process was repeated until the solvent became colourless. The supernatant was filtered through Whatman no. 1 filter paper and concentrated in vacuo under reduced pressure in a rotavapor (Heidolph) followed by lyophilisation. The lyophilised $B$. diffusa extract (BDE) was stored at $4^{\circ} \mathrm{C}$ until use. The yield of the extract was found to be $12.64 \%(\mathrm{w} / \mathrm{w})$. The same sample of the extract was used to conduct all the experiments.

The total phenolic content (TPC) of BDE was estimated using the Folin-Ciocalteu reagent ${ }^{(22)}$, and expressed as $\mathrm{mg}$ gallic acid equivalents/g extract. The total flavonoid content was determined using a colorimetric method ${ }^{(23)}$, and expressed as mg catechin equivalents/g extract. The angiotensinconverting enzyme (ACE)-inhibitory potential of BDE was assayed as reported by Hernandez-Ledesma et al. ${ }^{(24)}$. Briefly, different concentrations of BDE were added to $100 \mu$ hippurylL-histidyl-L-leucine, prepared in $50 \mathrm{~mm}$-HEPES buffer $(\mathrm{pH}$ 8.3 ) and then incubated for $5 \mathrm{~min}$ at $37^{\circ} \mathrm{C}$. The reaction was initiated by adding $150 \mu \mathrm{l}$ of $100 \mathrm{U} / 1 \mathrm{ACE}$ prepared in the same buffer and incubated for $1 \mathrm{~h}$ at $37^{\circ} \mathrm{C}$. The enzyme reaction was stopped by the addition of $0.5 \mathrm{M}-\mathrm{HCl}$ and the released hippuric acid was extracted with ethyl acetate. The organic layer was taken and evaporated at $90^{\circ} \mathrm{C}$ for $15 \mathrm{~min}$. The released hippuric acid was redissolved in distilled water and absorbance was measured at $228 \mathrm{~nm}$ using a UV-vis spectrophotometer (UV-2450PC; Shimadzu).

The inhibitory potential of xanthine oxidase (XO) was assayed spectrophotometrically according to the method of Owen \& Johns ${ }^{(25)}$. The assay mixture consisted of $1 \mathrm{ml} \mathrm{BDE}$ at different concentrations, $2.9 \mathrm{ml}$ of phosphate buffer $(\mathrm{pH} 7.5)$ and $0.1 \mathrm{ml}$ of enzyme solution ( 0.01 units/ $\mathrm{ml}$ in phosphate buffer, $\mathrm{pH} 7.5)$, which was prepared immediately before use. After preincubation at $25^{\circ} \mathrm{C}$ for $15 \mathrm{~min}$, the reaction was initiated by the addition of $2 \mathrm{ml}$ of substrate solution ( $150 \mathrm{~mm}$-xanthine in the same buffer). The assay mixture was incubated at $25^{\circ} \mathrm{C}$ for $30 \mathrm{~min}$. The reaction was then stopped by the addition of $1 \mathrm{ml}$ of $0.5 \mathrm{M}-\mathrm{HCl}$, and absorbance was measured at $290 \mathrm{~nm}$ using a UV-vis spectrophotometer (UV-2450PC; Shimadzu).

\section{Cell culture}

The H9c2 embryonic rat heart-derived cell line was obtained from the National Centre for Cell Science, Pune, India and cultured in Dulbecco's modified Eagle's medium (HiMedia) containing glucose $(4.5 \mathrm{~g} / \mathrm{l})$, sodium bicarbonate $(1.5 \mathrm{~g} / \mathrm{l})$ and sodium pyruvate $(110 \mathrm{mg} / \mathrm{l})$, supplemented with $10 \%$ fetal bovine serum (Gibco) and penicillin (100 units/ml) and streptomycin $(100 \mu \mathrm{g} / \mathrm{ml})$ in a humidified incubator with $95 \%$ air and $5 \% \mathrm{CO}_{2}$ at $37^{\circ} \mathrm{C}$. The culture medium was changed every $2 \mathrm{~d}$. After $4 \mathrm{~d}$, cells were passaged and seeded at a density of $1.2 \times 10^{6}$ cells per $100 \mathrm{~mm}$ dish or $0.64 \times 10^{4}$ cells per $6.4 \mathrm{~mm}$ well of ninety-six-well plates. These cells were cultured for $3 \mathrm{~d}$ and then underwent treatments.

\section{Cell treatment}

H9c2 cells were treated with BDE for $6 \mathrm{~h}$ before angiotensin II treatment. Angiotensin II (100 nm; Sigma-Aldrich) was prepared in double-distilled water, diluted with culture media to induce hypertrophy and cultured for an additional $48 \mathrm{~h}^{(7)}$. The experimental group consisted of (1) control cells (2) BDE-alone-treated cells, (3) angiotensin II-alone-treated cells and (4) BDE + angiotensin II-treated cells.

\section{Measurement of cell viability}

To carry out this experiment, $1 \times 10^{4}$ cells plated in each well of twenty-four-well plates were placed in a $5 \% \mathrm{CO}_{2}$ incubator 
at $37^{\circ} \mathrm{C}$ and allowed to adhere to the substrate. Cells grown to $70-85 \%$ confluence were exposed to various concentrations of $\operatorname{BDE}(1,10,25,50,75$ and $100 \mu \mathrm{g} / \mathrm{ml})$. BDE was dissolved in dimethyl sulphoxide and the final concentration of dimethyl sulphoxide used was less than $0 \cdot 1 \%(\mathrm{v} / \mathrm{v})$ for each treatment. The same concentration of dimethyl sulphoxide was used in control cells as vehicle. The control and treated cells were incubated for $48 \mathrm{~h}$. Cell viability was assayed using 3-(4,5-dimethylthiazol-2-yl)-2,5-diphenyltetrazolium bromide (Sigma-Aldrich) according to the standard protocol ${ }^{(26)}$.

\section{Lactate dehydrogenase release}

Lactate dehydrogenase (LDH) activity of the cells from all experimental groups (treated with angiotensin II and different concentrations of BDE) was measured using an LDH assay kit (Cayman Chemical) following the manufacturer's instructions.

\section{Measurement of cell size}

Adherent cells were made to detach via trypsinisation and images of rounded cells were acquired using a Nikon TE2000-S microscope with an attached digital camera and a $40 \times$ lens (Nikon). Measurements of cell diameter were made using Microsoft Office Document Imaging software (NIS Elements), and cell volume was calculated using the equation for the volume of a sphere $\left(4 / 3 \pi r^{3}\right)$. The diameter of individual cells was measured, and 100 cells per experimental group were measured randomly ${ }^{(27)}$.

\section{Measurement of protein content per cell}

Cells in the dishes after the respective treatments were collected by trypsinisation with trypsin-EDTA (HiMedia) and washed twice in ice-cold PBS. Cells were then collected via centrifugation and lysed with cell lysis buffer (20 mM-Tris$\mathrm{HCl}, 150 \mathrm{~mm}-\mathrm{NaCl}, 1 \mathrm{~mm}-\mathrm{Na}_{2}$ EDTA, $1 \mathrm{~mm}$-EGTA, $1 \%$ Triton $\mathrm{X}-100,2.5 \mathrm{~mm}$-sodium pyrophosphate, $1 \mathrm{~mm}-\beta$-glycerophosphate, $1 \mathrm{~mm}-\mathrm{Na}_{3} \mathrm{VO}_{4}, 1 \mu \mathrm{g}$ leupeptin/ml and $1 \mathrm{~mm}$-phenylmethylsulfonyl fluoride, $\mathrm{pH} 7 \cdot 5$ ) on ice for $30 \mathrm{~min}$. The suspension was centrifuged at $14000 \mathrm{~g}$ for $10 \mathrm{~min}$ at $4^{\circ} \mathrm{C}$, and the supernatant was collected. Protein concentration in the total cell lysate was measured using the Bradford assay ${ }^{(28)}$ with bovine serum albumin as the standard. Protein content per cell was determined by dividing the total amount of protein by the cell number ${ }^{(27)}$.

\section{Determination of atrial natriuretic peptide and B-type natriuretic peptide}

Atrial natriuretic peptide (ANP) and B-type natriuretic peptide (BNP) were measured using an ELISA kit (AssayPro).

\section{Assay of endogenous antioxidant status and lipid peroxidation}

Activities of various endogenous antioxidant enzymes were evaluated in the control and treated cells. Catalase activity was assayed by monitoring the disappearance of $\mathrm{H}_{2} \mathrm{O}_{2}$ at $240 \mathrm{~nm}$, according to the method of Aebi ${ }^{(29)}$. Superoxide dismutase activity was measured spectrophotometrically based on NADPH oxidation according to the method of Paoletti et $a l .{ }^{(30)}$. Glutathione peroxidase activity is based on the oxidation of reduced glutathione (GSH) by glutathione peroxidase coupled to the disappearance of NADPH by glutathione reductase ${ }^{(31)}$. The activity of glutathione reductase was measured by following the decrease in absorbance due to the oxidation of NADPH utilised in the reduction of oxidised glutathione according to the method of Goldberg \& Spooner ${ }^{(32)}$. GSH was quantified by using a fluorometric assay $^{(33)}$. Protein carbonyls and glutathione $S$-transferase were measured using a kit (Cayman Chemical).

The thiobarbituric acid-reactive substance (TBARS) assay was used to determine lipid peroxidation and was performed with a modified method as described previously ${ }^{(34)}$ in order to reduce the limitations such as heat-induced lipid peroxidation, interference of Fe released during homogenisation and sucrose.

\section{Detection of intracellular reactive oxygen species}

Intracellular ROS levels were measured employing fluorescent $2^{\prime}, 7^{\prime}$-dichlorodihydrofluorescein diacetate as a probe ${ }^{(35)}$. Live cell bioimaging was done with a high-content bioimager (BD Pathway ${ }^{\mathrm{TM}}$ Bioimager System; BD Biosciences).

\section{Expression of NF- $\kappa \beta$ and transforming growth factor $\beta 1$ using $R T-P C R$}

Total RNA was isolated from $\mathrm{H} 9 \mathrm{c} 2$ cells after the respective treatments using TRIzol reagent (Sigma-Aldrich) by the method described by Chomczynski \& Sacchi ${ }^{(36)}$.

The isolated RNA was used for RT-PCR to study the expression of $N F-\kappa \beta$ and $T G F-\beta 1$ at the mRNA level. Total RNA $(1.5 \mu \mathrm{g})$ was used in the reversal transcription reaction with $0.5 \mu \mathrm{g}$ oligo-dT16 (Fermentas), $10 \mathrm{~mm}$ of each of the

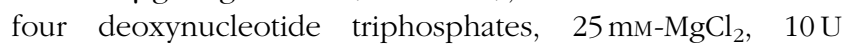
RNase inhibitor and $50 \mathrm{U}$ RT (Fermentas) according to the manufacturer's instructions.

The primer sequences used were as follows: $N F-\kappa \beta-$ forward 5'-CCTAGCTTTCTCTGAACTGCAAA- ${ }^{\prime}$, reverse 5'-GGGTCAGAGGCCAATAGAGA- $3^{\prime}$; TGF- $\beta 1$ - forward $5^{\prime}$-GGC-CAG-ATCCTG-TCC-AAA-CT- $3^{\prime}$, reverse $\quad 5^{\prime}$-GCC-CTG-TAT-TCC-GTCTCCTT-3'; glyceraldehyde 3-phosphate dehydrogenase - forward 5'-GCCAAAAGGGTCATCATCTCCGC-3', reverse 5'-GGATGACCTGCCCACAGCCTTG- $3^{\prime}$. The PCR mixture contains

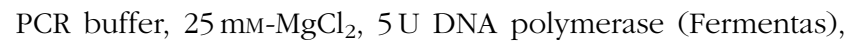
$3 \mu \mathrm{l}$ complementary DNA and $20 \mathrm{pmol}$ of each primer for thirty-five cycles. The PCR products were electrophoresed in $1 \%$ agarose gels containing $0.05 \mu \mathrm{g} / \mathrm{ml}$ of ethidium bromide. mRNA expression was quantified using a phosphoimager and accompanying Image Quant software (Bio Rad), and the relative expression was compared and normalised to the expression of glyceraldehyde 3-phosphate dehydrogenase in the same sample. 


\section{Statistical analysis}

Results are expressed as means and standard deviations of the control and treated cells from three independent experiments in duplicate ( $n$ 6). Data were subjected to one-way ANOVA and the significance of differences between means was calculated by Duncan's multiple range test using SPSS for Windows, standard version 7.5.1 (SPSS, Inc.), and significance was accepted at $P \leq 0 \cdot 05$.

\section{Results \\ Cell viability}

Cell viability analysis revealed that BDE did not possess any cytotoxicity in $\mathrm{H} 9 \mathrm{c} 2$ cells (data not shown). Cells treated with angiotensin II alone and BDE with angiotensin II were also evaluated for their viability. Treatment with BDE protected the cells from angiotensin II-induced cell death in a dose-dependent manner, and BDE at a concentration of $75 \mu \mathrm{g} / \mathrm{ml}$ exhibited maximum activity (Fig. 1(a)). The activity of $\mathrm{LDH}$ increased significantly in the angiotensin II-treated hypertrophied cells while BDE + angiotensin II-treated cells showed reduced LDH activity, indicating the cytoprotective potential of BDE (Fig. 1(b)). There was no significant change in the activity of this enzyme in BDE-alone-treated cells when compared with the control cells. Since the BDE concentration of $75 \mu \mathrm{g} / \mathrm{ml}$ was found to be more protective, we used this dose for evaluating other parameters relevant to hypertrophy.

\section{Cell volume, protein content and the concentrations of atrial natriuretic peptide and B-type natriuretic peptide}

Angiotensin II caused an increase in cell volume (69.26 (SD 1.21)\%), protein content (48.48 (SD 1.64)\%), ANP (81.90 (SD 1.22)\%) and BNP (108.57 (SD 1.47)\%) (Table 1). The BDE treatment significantly reduced cell volume, protein content and the concentrations of ANP and BNP $(P \leq 0.05)$ in the angiotensin II-treated cells. This indicates the antihypertrophic potential of BDE.

\section{Antioxidant status}

Fig. 2(a) and (b) represents intracellular ROS production in the control and treated cells. The angiotensin II treatment caused increased ROS generation while the BDE treatment reduced the generation of ROS. Evaluation of endogenous antioxidant status during hypertrophy provides an indication of oxidative damage. For this purpose, we measured the concentration of TBARS and the activities of various antioxidant enzymes such as catalase, superoxide dismutase, glutathione peroxidase, glutathione reductase and glutathione $S$-transferase (Table 2). The concentration of TBARS was higher (92.71 (SD 1.21)\%) in the hypertrophied cells when compared with the control cells, while the BDE + angiotensin II-treated cells showed a $39 \cdot 86$ (SD $2 \cdot 1$ ) \% reduction in the concentration of TBARS when compared with the hypertrophied cells $(P \leq 0 \cdot 05)$. Depletion of GSH (38.22 (SD 1.92)\%), a non-enzymatic antioxidant,
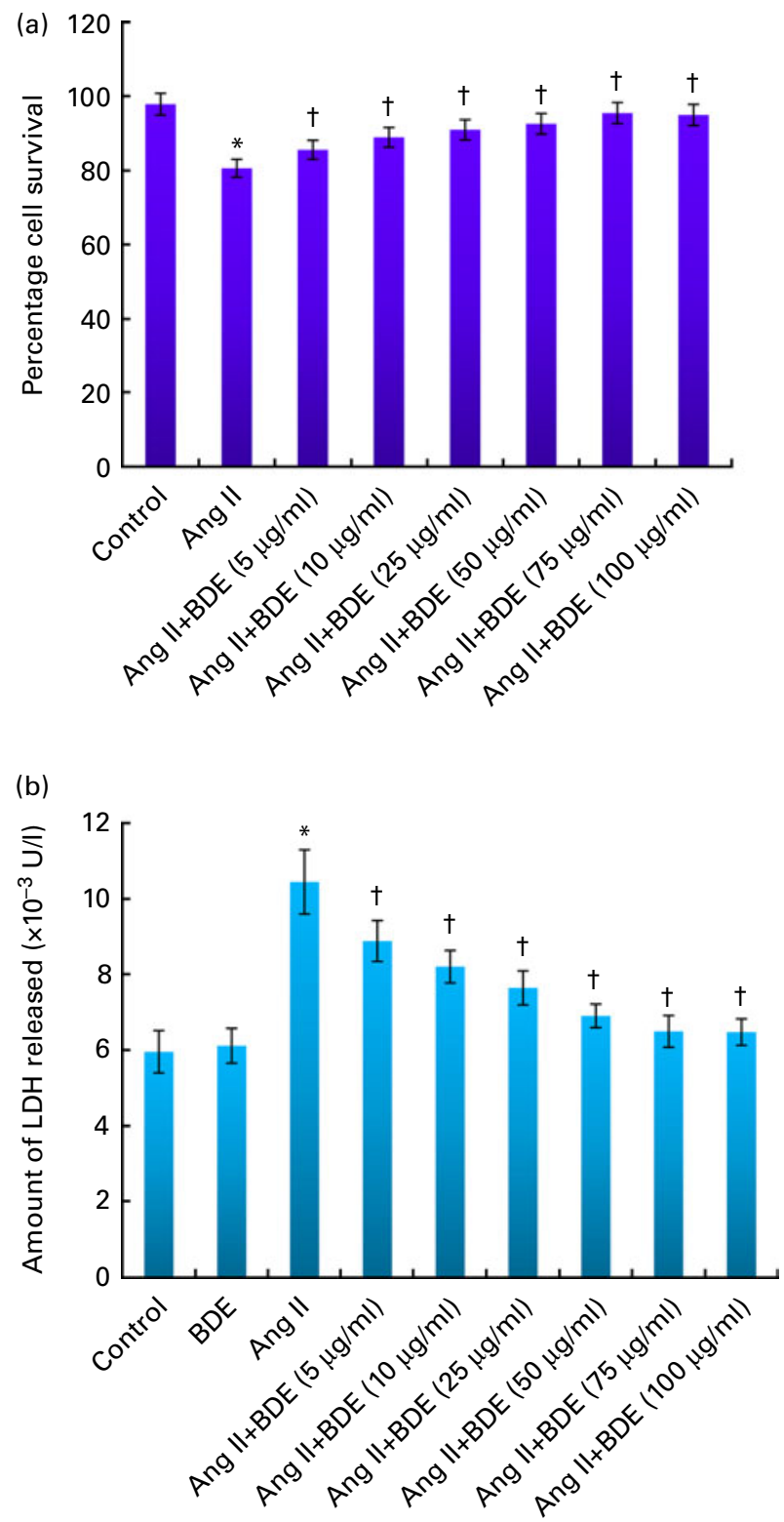

Fig. 1. (a) Viability of $\mathrm{H} 9 \mathrm{c} 2$ cells treated with angiotensin II (Ang II) and different concentrations of Boerhaavia diffusa extract (BDE) + Ang II. (b) Activity of lactate dehydrogenase (LDH) in the control and treated cells. Values are means, with standard deviations represented by vertical bars $(n 6)$. * Mean value was significantly different from the control cells $(P \leq 0.05)$. †Mean values were significantly different from the Ang II-treated cells $(P \leq 0.05)$. (A colour version of this figure can be found online at http://www.journals. cambridge.org/bjn)

was observed in the angiotensin II-treated cells, while the BDE pretreated cells significantly prevented the decrease in GSH. Activities of the antioxidant enzymes (catalase, superoxide dismutase, glutathione peroxidase, glutathione reductase and glutathione $S$-transferase) were significantly reduced (42.65 (SD 1.33), 76 (SD 1.92), 46 (SD 1.51), 51 (SD .12) and 60 (SD 1.08$) \%$, respectively) in the angiotensin II-treated cells when compared with the untreated control cells $(P \leq 0.05)$, while the BDE treatment reversed these changes. This validates the antioxidant-mediated protection by BDE in the hypertrophied cells. Oxidative stress is also associated 
(a)
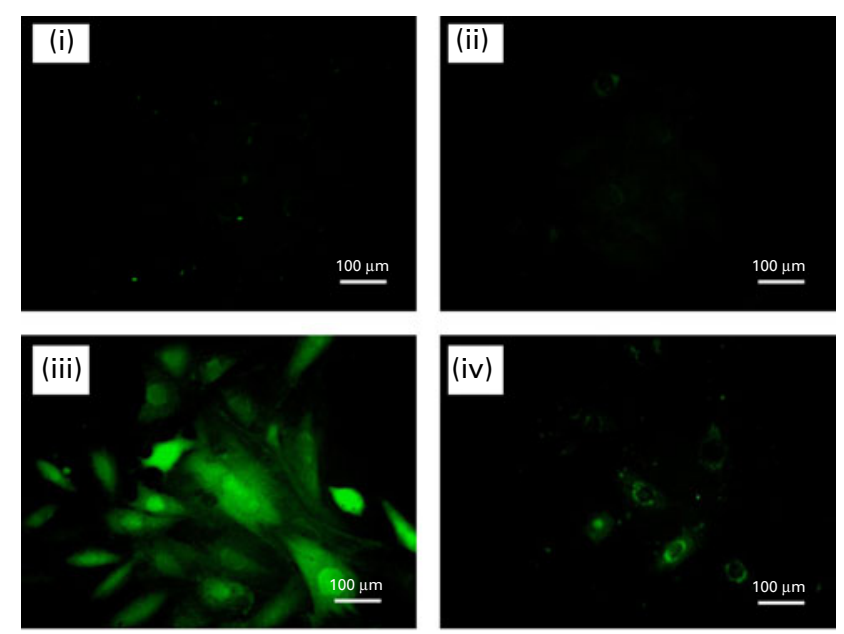

(b)

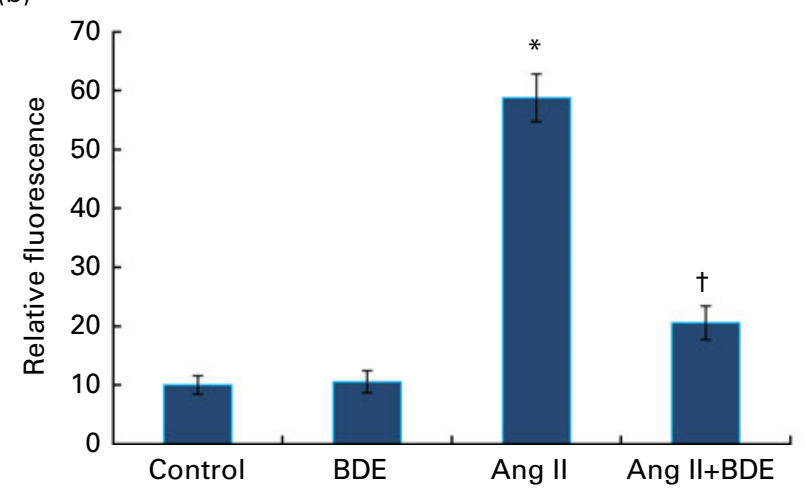

Fig. 2. (a) Effect of Boerhaavia diffusa extract (BDE) on intracellular reactive oxygen species (ROS) generation in the control and hypertrophied H9c2 cells. The representative photographs of ROS-induced fluorescence by the cells treated with angiotensin II (Ang II) and BDE. (i) Control cells, (ii) BDE (75 $\mu \mathrm{g} / \mathrm{ml}$ )-alone-treated cells, (iii) Ang II (100 nM)-treated cells and (iv) Ang II + BDE-treated cells. (b) Amount of ROS release measured as fluorescence. Values are means, with standard deviations represented by vertical bars $(n 6) .{ }^{*}$ Mean value was significantly different from the control cells $(P \leq 0.05)$. † Mean value was significantly different from the angiotensin II-treated cells $(P \leq 0.05)$. (A colour version of this figure can be found online at http://www.journals.cambridge.org/bjn)

with protein oxidation and the concentration of protein carbonyls was also significantly higher (125.22 (SD 1.52)\%) in the hypertrophied cells (Table 2). Here, the BDE treatment also significantly reduced the concentration of protein carbonyls when compared with the hypertrophied cells $(P \leq 0 \cdot 05)$.

\section{Expression of NF- $\kappa \beta$ and transforming growth factor $\beta 1$}

The mRNA expressions of $N F-\kappa \beta$ and $T G F-\beta 1$ were evaluated by RT-PCR (Figs. 3 and 4, respectively). The angiotensin II-treated cells showed a marked increase in NF-к $\beta$ and TGF- $\beta 1$ expressions compared with the control cells $(P \leq 0 \cdot 05)$. The BDE treatment reduced the expression of the $N F-\kappa \beta$ (Fig. 3(a) and (b)) and TGF- $\beta 1$ (Fig. 4(a) and (b)) genes $(P \leq 0.05)$. There was no change in their expression in the BDE-alone-treated cells.
The TPC and the total flavonoid content of BDE were estimated to be 125.02 (SD 1.56) $\mathrm{mg}$ gallic acid equivalents/g and $63 \cdot 15$ (SD 2.48) $\mathrm{mg}$ catechin equivalents/g extract, respectively. In addition, in vitro chemical assays revealed that BDE exhibited inhibitory potential against ACE and XO in a dose-dependent manner. The estimated $50 \%$ effective concentration $\left(\mathrm{EC}_{50}\right)$ value for BDE against $\mathrm{ACE}$ inhibition was $166 \cdot 12$ (SD 2.42$) \mu \mathrm{g} / \mathrm{ml}$ and that of the standard compound captopril was $1.2(\mathrm{SD} 0 \cdot 22) \mu \mathrm{g} / \mathrm{ml}$. BDE showed XO inhibition with an estimated $\mathrm{EC}_{50}$ value of 60.05 (SD 1.54) $\mu \mathrm{g} / \mathrm{ml}$ and that of the standard compound allopurinol was $6 \cdot 11$ (SD 1.27) $\mu \mathrm{g} / \mathrm{ml}$.

\section{Discussion}

The present study has shown the protective potential of $B$. diffusa against angiotensin II-induced cardiac hypertrophy in $\mathrm{H} 9 \mathrm{c} 2$ cells. The $\mathrm{H} 9 \mathrm{c} 2$ cell line was originally derived from the embryonic rat ventricular tissue ${ }^{(37)}$, which is important to study hypertrophy since cardiac hypertrophy resulting from hypertension mainly occurs in the ventricular muscle of the heart ${ }^{(38)}$. H9c2 cells show many similarities to primary cardiomyocytes, including membrane morphology, G-signalling protein expression and electrophysiological properties ${ }^{(39,40)}$. Importantly, they can display a wide range of hypertrophyassociated traits when stimulated with hypertrophic agents in vitro ${ }^{(38)}$. Angiotensin II, the active octapeptide and circulatory hormone, is an important humoral factor responsible for cardiomyocyte hypertrophy ${ }^{(41)}$, and is emerging as an important molecule both in the development of cardiac hypertrophy and in the pathogenesis of progressive myocardial dysfunction leading to heart failure ${ }^{(42)}$. A reduction in cell size, protein content, LDH leakage and the down-regulation of ANP and BNP upon BDE treatment in the angiotensin II-exposed cells shows the beneficial effects of BDE against cardiac hypertrophy.

Direct evaluation of ROS yields a very good indication of oxidative damage to living cells ${ }^{(43)}$. Elevated levels of ROS impair cardiomyocyte function by damaging ion channels as well as inhibiting contractility, and can disrupt the structural integrity of ion channels via membrane lipid peroxidation at the cellular level ${ }^{(44)}$. Reduced generation of ROS upon BDE treatment shows the free-radical-scavenging potential of BDE. Since ROS act as a signalling molecule for the development of cardiac hypertrophy, agents that block the formation of ROS will have therapeutic importance against cardiac hypertrophy. Increased ROS generation is mainly due to the depletion of an endogenous antioxidant system ${ }^{(45)}$. This reduces the capacity of cells to scavenge various types of reactive radicals and cause oxidative stress in cells. Increased quantities of ROS initiate lipid peroxidation in cellular, mitochondrial and nuclear membranes along with protein oxidation $^{(46)}$. The TBARS assay is the most commonly used method for measuring lipid peroxidation, but the method also suffers from some limitations ${ }^{(47)}$. One of the limitations is interference from Fe released during homogenisation ${ }^{(47,48)}$ and another limitation is sporadic lipid peroxidation during heating ${ }^{(34)}$. In the in vitro experiments, sucrose can also interfere with the assay. In order to reduce the interference of $\mathrm{Fe}$ 
Table 1. Change in cell volume, protein content, atrial natriuretic peptide (ANP) and B-type natriuretic peptide (BNP) in the control and treated cells

(Mean values and standard deviations, $n 6$ )

\begin{tabular}{|c|c|c|c|c|c|c|c|c|}
\hline \multirow[b]{2}{*}{ Parameters } & \multicolumn{2}{|c|}{ Control } & \multicolumn{2}{|c|}{ BDE alone } & \multicolumn{2}{|c|}{ Angiotensin II } & \multicolumn{2}{|c|}{$\begin{array}{c}\text { Angiotensin } \\
\text { II + BDE }\end{array}$} \\
\hline & Mean & SD & Mean & SD & Mean & SD & Mean & SD \\
\hline Cell volume $\left(\mu \mathrm{m}^{3} \times 10^{3}\right)$ & $2 \cdot 31$ & 0.12 & 2.35 & 0.14 & $3 \cdot 91^{*}$ & 0.21 & $2.95 \dagger$ & 0.15 \\
\hline Protein content ( $\mathrm{mg} \times 10^{6}$ cells) & 0.33 & 0.017 & 0.34 & 0.015 & $0.49^{\star}$ & 0.022 & $0.39 \dagger$ & 0.017 \\
\hline ANP $(\mathrm{ng} / \mathrm{ml})$ & 1.05 & 0.041 & 1.04 & 0.052 & $1.91^{*}$ & 0.091 & $1.31 \dagger$ & 0.081 \\
\hline $\mathrm{BNP}(\mathrm{ng} / \mathrm{ml})$ & 0.035 & 0.012 & 0.037 & 0.009 & $0.073^{*}$ & 0.022 & $0.042 \dagger$ & 0.014 \\
\hline
\end{tabular}

BDE, Boerhaavia diffusa extract.

${ }^{*}$ Mean values were significantly different from the control cells $(P \leq 0.05)$.

$\dagger$ Mean values were significantly different from the angiotensin II-treated hypertrophied cells $(P \leq 0.05)$.

and heat-induced lipid peroxidation, the addition of an antioxidant such as butylated hydroxytoluene is advised ${ }^{(47,48)}$. To prevent sucrose interference, boiled samples can be extracted with butanol-pyridine solution ${ }^{(49)}$. In the present study, in order to reduce the interference from heating and Fe-induced peroxidation, butylated hydroxytoluene was added to the reaction mixture and lipid peroxides were extracted with butanol. Protein carbonyls are the products of protein oxidation and are one of the most commonly used markers of protein oxidation ${ }^{(50)}$. An increased level of TBARS and protein carbonyls along with a reduced concentration of GSH in the angiotensin II-treated cells showed oxidative damage during hypertrophy. In addition, hypertrophied H9c2 cells showed reduced activities of antioxidant enzymes. Intracellular antioxidant enzymes act as a first line of defence against oxidative stress in the cell. Among the various antioxidant enzymes, superoxide dismutase catalyses the dismutation of the superoxide anion to $\mathrm{H}_{2} \mathrm{O}_{2}$ and molecular $\mathrm{O}_{2}$. $\mathrm{H}_{2} \mathrm{O}_{2}$ is decomposed to $\mathrm{H}_{2} \mathrm{O}$ by catalase and glutathione peroxidase. In the reaction catalysed by glutathione peroxidase, GSH is oxidised to oxidised glutathione, which can be subsequently reduced back to GSH by glutathione reductase ${ }^{(51)}$. Decreased activities of GSH-dependent enzymes such as glutathione peroxidase and glutathione reductase in hypertrophied cells may be due to either free radical-dependent inactivation of enzyme or depletion of GSH. GSH is one of the major non-enzymatic antioxidants and a powerful nucleophile critical for cellular protective activities such as detoxification of ROS and control of the inflammatory cytokine cascade $^{(52)}$. Depletion of GSH leads to the impairment of cellular defence against ROS and may lead to oxidative injury ${ }^{(53)}$. GSH can also act as a cofactor for glutathione $S$-transferase. Glutathione $S$-transferase plays an important role in protecting cells against ROS-mediated injury through catalysing the decomposition of lipid peroxides produced during the ROS attack of cellular lipid molecules ${ }^{(51)}$. The beneficial effects of BDE in reducing oxidative stress during hypertrophy are due to its antioxidant potential.

The results of the in vitro chemical assays revealed that BDE exhibits XO-and ACE-inhibitory potential. Generally, ROS are derived from the superoxide anion. One of the major enzymatic sources that generate the superoxide anion in the myocardium is $\mathrm{XO}$, and previous studies have shown that the activity of $\mathrm{XO}$ was higher during cardiac dysfunction $^{(44)}$. The XO-inhibitory potential of BDE further confirms that the extract can scavenge ROS-producing superoxide anions and thereby protect the myocardium against oxidative stress-mediated hypertrophy. Likewise, the ACE-inhibitory potential of BDE also contributes to its protection against cardiac hypertrophy. It was established that ACE inhibition is

Table 2. Concentration of thiobarbituric acid-reactive substances (TBARS) and activities of antioxidant enzymes in the control and treated cells

(Mean values and standard deviations, $n 6$ )

\begin{tabular}{|c|c|c|c|c|c|c|c|c|}
\hline \multirow[b]{2}{*}{ Parameters } & \multicolumn{2}{|c|}{ Control } & \multicolumn{2}{|c|}{$\mathrm{BDE}$} & \multicolumn{2}{|c|}{ Angiotensin II } & \multicolumn{2}{|c|}{$\begin{array}{c}\text { Angiotensin } \\
\text { II + BDE }\end{array}$} \\
\hline & Mean & SD & Mean & SD & Mean & SD & Mean & SD \\
\hline TBARS (nmol MDA/mg protein) & 1.51 & 0.08 & 1.59 & 0.05 & $2 \cdot 91^{*}$ & 0.15 & $1.75 t$ & 0.12 \\
\hline Catalase ( $\mu \mathrm{mol} \mathrm{H}_{2} \mathrm{O}_{2}$ decomposed/min per mg protein) & $0 \cdot 14$ & 0.02 & 0.15 & 0.04 & $0.08^{*}$ & 0.03 & $0.13 \dagger$ & 0.01 \\
\hline SOD (units/mg protein) & 0.21 & 0.03 & 0.19 & 0.05 & $0.05^{\star}$ & 0.02 & $0.132 \dagger$ & 0.02 \\
\hline GPX (units/mg protein) & 0.65 & 0.06 & 0.67 & 0.04 & $0.35^{\star}$ & 0.05 & $0.50 t$ & 0.06 \\
\hline GRD (units/mg protein) & 0.39 & 0.02 & 0.41 & 0.04 & $0.19^{*}$ & 0.05 & $0.31 \dagger$ & 0.04 \\
\hline GST (nmol/min per ml) & 4.51 & 0.61 & 4.60 & 0.69 & $1 \cdot 80^{*}$ & 0.55 & $3.99 \dagger$ & 0.27 \\
\hline GSH (nmol/mg protein) & $11 \cdot 25$ & 0.94 & 11.34 & $1 \cdot 14$ & $6 \cdot 95^{\star}$ & 0.85 & $9.83 \dagger$ & 0.98 \\
\hline Protein carbonyls $(\mathrm{nmol} / \mathrm{ml})$ & $3 \cdot 29$ & 0.46 & $3 \cdot 17$ & 0.51 & $7 \cdot 41^{*}$ & 0.68 & $4 \cdot 31 \dagger$ & 0.58 \\
\hline
\end{tabular}

BDE, Boerhaavia diffusa extract; MDA, malondialdehyde; SOD, superoxide dismutase; GPX, glutathione peroxidase; GRD, glutathione reductase;

GST, glutathione S-transferase; GSH, reduced glutathione.

${ }^{*}$ Mean values were significantly different from the control cells $(P \leq 0.05)$.

† Mean values were significantly different from the angiotensin II-treated hypertrophied cells $(P \leq 0.05)$. 
(a) Control BDE Ang II Ang II+BDE
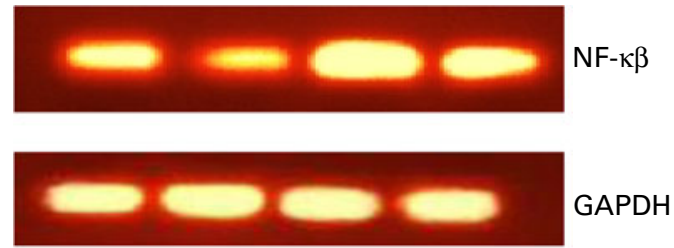

(b)

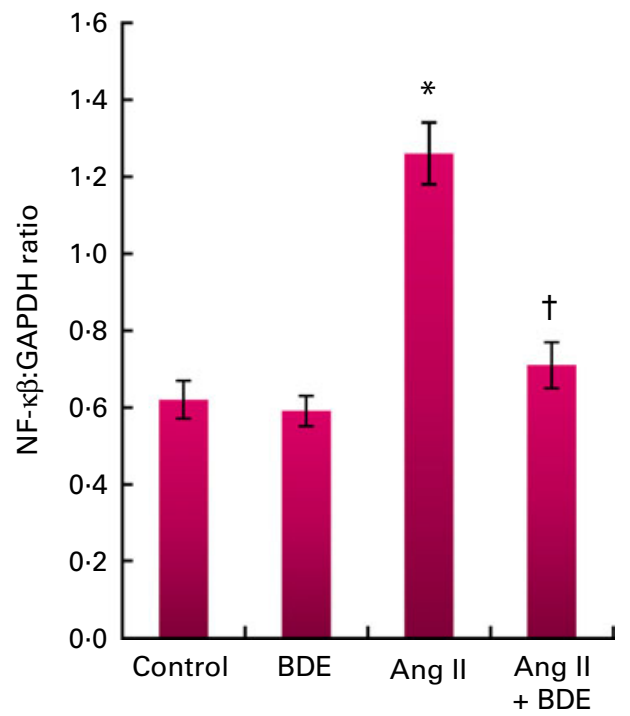

Fig. 3. (a) Expression of $N F-\kappa \beta$ at the mRNA level using RT-PCR. (b) Graphical representation of the intensity of NF-к $\beta$ expression. Values are means, with standard deviations represented by vertical bars $(n 6)$. * Mean value was significantly different from the control cells (Cont, $P \leq 0.05$ ). $\dagger$ Mean value was significantly different from the angiotensin II (Ang II)-treated cells $(P \leq 0.05)$. GAPDH, glyceraldehyde 3-phosphate dehydrogenase; $\mathrm{BDE}$, Boerhaavia diffusa extract. (A colour version of this figure can be found online at http://www.journals.cambridge.org/bjn)

associated with a significant improvement in cardiac hypertrophy secondary to hypertension and favourably affects coronary haemodynamics ${ }^{(54)}$.

In order to study the effects of angiotensin II-induced cardiac hypertrophy on transcription factors, mRNA expressions of $N F-\kappa \beta$ and $T G F-\beta 1$ were studied in H9c2 cells. $\mathrm{NF}-\kappa \beta$ is an inducible transcription factor that is activated by various inflammatory stimuli and growth factors, and is involved in inflammation, immune response and cell survi$\mathrm{val}^{(55)}$. NF-к $\beta$ also influences the regulation of cell growth, and the activation of NF-к $\beta$ is closely linked with cardiac hypertrophy and required for the hypertrophic growth of cardiomyocytes both in vitro and in vivo ${ }^{(56,57)}$. ROS can act as a strong stimulus for the activation of NF- $\kappa \beta^{(58,59)}$ and treatment with antioxidants can abolish the angiotensin II-induced hypertrophic response of cardiomyocytes through inhibiting NF- $\beta$ activation ${ }^{(57)}$. A decrease in the mRNA expression of $N F-\kappa \beta$ may be due to the decrease in the activation of NF- $\kappa \beta$. The decreased mRNA level of $N F-\kappa \beta$ in BDE-treated cells indicates that BDE can down-regulate the expression of $\mathrm{NF}-\kappa \beta$ via reducing the generation of ROS. Reports have shown that $A N P$ gene expression requires NF-к $\beta$ activation ${ }^{(57)}$.
We found in the present study that the concentration of ANP increased along with the activation of NF-к $\beta$. TGF- $\beta 1$ is another transcription factor involved in the regulation of development, differentiation, the maintenance and repair of various cells and tissues, and it has been shown to be expressed at high levels during the cardiac development and pathology of the heart ${ }^{(60)}$. TGF- $\beta 1$ is present in both cardiomyocytes and myocardial fibroblasts, and is an important mediator of the hypertrophic growth of the heart ${ }^{(61)}$. Also, in the present study, the mRNA expression of TGF- $\beta 1$ was significantly increased in angiotensin II-treated cells, which is in agreement with previous reports ${ }^{(61)}$. Treatment with BDE reduced the expression of $T G F-\beta 1$ mRNA levels, indicating that BDE can down-regulate the hypertrophic response induced by angiotensin II. Blocking the TGF- $\beta 1$ pathway might be a pharmacological intervention in cardiac remodelling involving cardiac hypertrophy ${ }^{(62)}$.

From the overall results, it is clear that $B$. diffusa is a potent pharmacological agent that exerts significant protection against the angiotensin II-induced hypertrophic response in H9c2 cells by reducing oxidative stress and down-regulating transcription factors such as $N F-\kappa \beta$ and TGF- $\beta 1$. B. diffusa is
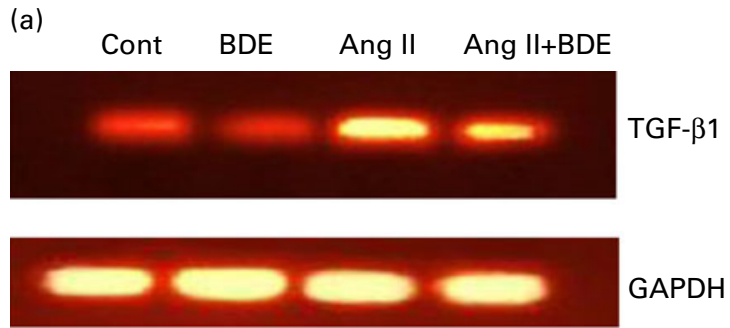

(b)

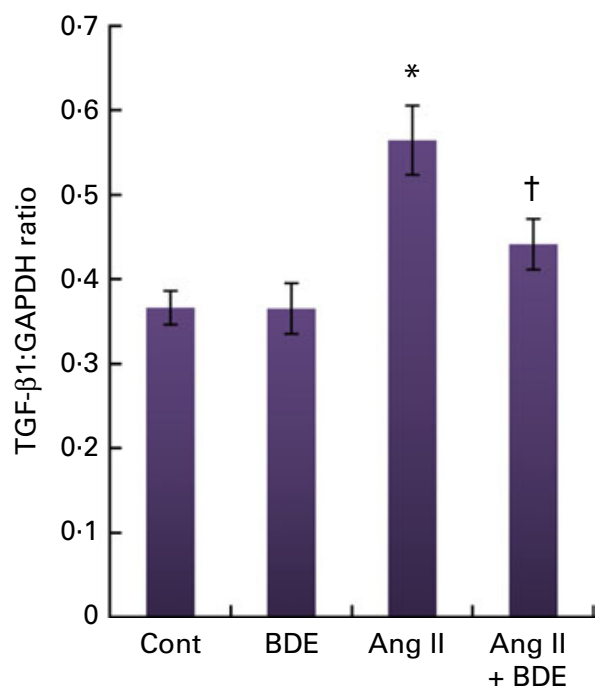

Fig. 4. (a) Expression of transforming growth factor $\beta 1$ (TGF- $\beta 1$ ) at the mRNA level using RT-PCR. (b) Graphical representation of the intensity of TGF- $\beta 1$ expression. Values are means, with standard deviations represented by vertical bars $(n 6)$. * Mean value was significantly different from the control cells (Cont, $P \leq 0.05$ ). † Mean value was significantly different from the angiotensin II (Ang II)-treated cells $(P \leq 0 \cdot 05)$. GAPDH, glyceraldehyde 3-phosphate dehydrogenase; BDE, Boerhaavia diffusa extract. (A colour version of this figure can be found online at http://www.journals.cambridge.org/bjn) 
a rich source of phenolic compounds that are potent natural antioxidants $^{(19,20)}$. In the present study, the TPC of $B$. diffusa was estimated to be 125.02 (SD 1.56) mg gallic acid equivalents/g extract, which is comparable with the study of Apu et $a l^{(12)}$ (TPC 163.14 (SD 1.95) $\mathrm{mg} / \mathrm{g}$ extract). In contrast, others have reported less TPC values such as $24 \cdot 28$ (SD 3$)^{(17)}$ and $5.54(\mathrm{SD} 0.24) \mathrm{mg} / \mathrm{g}$ extract $^{(20)}$ and the reduced TPC content may be due to the differences in geographical distribution, the season of plant collection and the extraction of plant material. Polyphenols have recently attracted considerable attention for the prevention of oxidative stress ${ }^{(6)}$, and epidemiological studies have shown that consumption of phenolics and flavonoids has modestly reduced the risks for CVD and acts as protective agents against $\mathrm{CVD}^{(9,19,63)}$. Previous studies have shown that BDE contains a number of pharmacologically active compounds such as punarnavine, ursolic acid, punarnavoside, liriodendrin, eupalitin, rotenoids (boeravinones A, B, C, D, E, F and G), quercetin, kaempferol, etc. $^{(14,64,65)}$. Studies on $B$. diffusa have revealed that it can scavenge ROS and is effective in reducing diseases associated with oxidative stress ${ }^{(18-20)}$. Among the various active compounds, quercetin is found to be effective in reducing left ventricular cardiac hypertrophy in a variety of experimental models ${ }^{(66)}$. Quercetin also exerts protection against endothelial dysfunction and exhibits antihypertensive effects ${ }^{(67)}$. Ursolic acid and kaempferol are other active compounds from $B$. diffusa, which have also been reported to possess cardioprotective properties ${ }^{(68,69)}$. Liriodendrin isolated from B. diffusa exhibits Ca channel antagonistic properties in the heart cell, which is attributed to its cardioprotective and antihypertensive potential ${ }^{(70)}$. Boeravinone $G$, a rotenoid from $B$. diffusa, is a potent antioxidant and genoprotective agent $^{(18)}$. The observed beneficial effects of $B$. diffusa against hypertrophy may be due to the presence of these biologically active molecules.

In conclusion, the results obtained in the present study have shown that BDE protects $\mathrm{H} 9 \mathrm{c} 2$ cardiac myocytes against angiotensin II-induced cardiac hypertrophy. The possible beneficial effect of BDE in reducing cardiac hypertrophy appears to be by the down-regulation of oxidative stress and transcription factors such as $N F-\kappa \beta$ and $T G F-\beta 1$. Since the plant is widely used as a vegetable, $B$. diffusa can be used as a nutraceutical/medicinal food for the prevention and management of cardiac hypertrophy and other associated disorders. However, further detailed studies are required to establish its clinical relevance/therapeutic potential.

\section{Acknowledgements}

A. P. thanks the Council of Scientific and Industrial Research for financial assistance in the form of Senior Research Fellowship. We are also thankful to the CSIR 12th 5-year plan project 'THUNDER' (BSC 0102) for partial financial assistance. We thank the Director, CSIR-NIIST and Head, Agroprocessing and Natural Products Division, CSIR-NIIST for providing necessary facilities. A. P. designed and conducted the experiments, analysed the results and prepared the manuscript. V. P. V. and P. A. A. also conducted the experiments and analysed the data. K. G. R. contributed to the conception and design of the study, the acquisition and interpretation of the data, performed the analysis and drafted the manuscript for important intellectual content. All the authors participated sufficiently in the work. The authors declare that there is no conflict of interest.

\section{References}

1. Drazner MH, Rame JE, Marino EK, et al. (2004) Increased left ventricular mass is a risk factor for the development of a depressed left ventricular ejection fraction within five years: the Cardiovascular Health Study. J Am Coll Cardiol 43, 2207-2215.

2. Liu CJ, Cheng YC, Lee KW, et al. (2008) Lipopolysaccharide induces cellular hypertrophy through calcineurin/NFAT-3 signalling pathway in H9c2 myocardiac cells. Mol Cell Biochem 313, 167-178.

3. Papparella I, Ceolotto G, Montemurro D, et al. (2008) Green tea attenuates angiotensin II induced cardiac hypertrophy in rats by modulating reactive oxygen species production and the Src/Epidermal growth factor receptor/Akt signalling pathway. J Nutr 138, 1596-1601.

4. Yao FR, Sun CW \& Chang SK (2010) Morton lentil extract attenuated angiotensin II induced cardiomyocyte hypertrophy via inhibition of intracellular reactive oxygen species levels in vitro. J Agric Food Chem 58, 10382-10388.

5. Takimoto E \& Kass DA (2007) Role of oxidative stress in cardiac hypertrophy and remodelling. Hypertension 49, $241-248$.

6. Li HL, Wang AB, Huang Y, et al. (2005) Isorhapontigenin, a new resveratrol analog, attenuates cardiac hypertrophy via blocking signalling transduction pathways. Free Rad Biol Med 38, 243-257.

7. Alissa EM \& Ferns GA (2012) Functional foods and nutraceuticals in the primary prevention of cardiovascular diseases. J Nutr Metabol 2012, article ID 569486.

8. Ames MK, Shigenaga MK \& Hagen TM (1993) Oxidants, antioxidants and the degenerative disease of aging. Proc Natl Acad Sci U S A 90, 7915-7922.

9. Stampfer MJ, Hu FB, Manson JE, et al. (2000) Primary prevention of coronary heart disease in women through diet and lifestyle. New Eng J Med 343, 16-22.

10. Kaur M \& Goel RK (2011) Anti-convulsant activity of Boerhaavia diffusa: plausible role of calcium channel antagonism. Evid Based Complement Alternat Med 4, 1-7.

11. Srivastava R, Saluja D, Dwarakanath BS, et al. (2011) Inhibition of human cervical cancer cell growth by ethanolic extract of Boerhaavia diffusa Linn. (Punarnava) root. Evid Based Complement Alternat Med 2011, article ID 427031.

12. Apu AS, Liza MS, Jamaluddin ATM, et al. (2012) Phytochemical screening and in vitro bioactivities of the extracts of aerial part of Boerhaavia diffusa Linn. Asian Paci J Trop Biomed 2, 673-678.

13. Munasinghe TCJ, Seneviratne CK, Thabrew IM, et al. (2001) Antiradical and antilipoperoxidative effects of some plant extracts used by Sri Lankan traditional medical practitioners for cardioprotection. Phytother Res 15, 519-523.

14. Agrawal M, Nandini D, Sharma V, et al. (2010) Herbal remedies for the treatment of hypertension. Int J Pharm Sci and Res 1, 1-21.

15. Pari L \& Satheesh AM (2004) Antidiabetic effect of Boerhaavia diffusa: effect on serum and tissue lipids in experimental diabetes. J Med Food 7, 472-476. 
16. Manu KA \& Kuttan G (2009) Immunomodulatory activities of Punarnavine, an alkaloid from Boerhaavia diffusa. Immunopharmacol Immunotoxicol 31, 377-387.

17. Sreeja S \& Sreeja S (2009) An in vitro study on antiproliferative and antiestrogenic effects of Boerhaavia diffusa L. extracts. J Ethnopharmacol 126, 221-225.

18. Aviello G, Canadanovic-Brunet JM, Milic N, et al. (2011) Potent antioxidant and genoprotective effects of Boeravinone $G$, a rotenoid isolated from Boerhaavia diffusa. Plos One 6, e19628.

19. Prathapan A, Singh MK, Anusree SS, et al. (2011) Antiperoxidative, free radical scavenging and metal chelating activities of Boerhaavia diffusa L. J Food Biochem 35, 1548-1554.

20. Gulati V, Harding IH \& Palombo EA (2012) Enzyme inhibitory and antioxidant activities of traditional medicinal plants: potential application in the management of hyperglycemia. BMC Compl Alt Med 12, 77.

21. Pareta SK, Patra KC, Mazumder PM, et al. (2011) Aqueous extract of Boerhaavia diffusa root ameliorates ethylene glycol-induced hyperoxaluric oxidative stress and renal injury in rat kidney. Pharm Biol 49, 1224-1233.

22. Singleton VL \& Rossi JA (1965) Colorimetry of total phenolics with phosphomolybdic-phosphotungstic acid reagents. Am J Enol Viticult 16, 144-158.

23. Jia Z, Mengcheng $\mathrm{T} \& \mathrm{Wu} \mathrm{J}$ (1999) The determination of flavanoid contents in mulberry and their scavenging effects on superoxide radicals. Food Chem 64, 555-559.

24. Hernandez-Ledesma B, Martin-Alvarez PJ \& Pueyo E (2003) Assessment of the spectrometric method for determination of angiotensin-converting enzyme activity: influence of the inhibition type. J Agri Food Chem 51, 4175-4179.

25. Owen PL \& Johns T (1999) Xanthine oxidase inhibitory activity of northeastern North American plant remedies used for gout. J Ethnopharmacol 64, 149-160.

26. Wilson AP (2000) Cytotoxicity and viability assays. In Animal Cell Culture: A Practical Approach, 2nd ed., pp. 175-219 [JRW Masters, editor]. Oxford: Oxford University Press.

27. Merten KE, Jiang Y, Feng W, et al. (2006) Calcineurin activation is not necessary for Doxorubicin-induced hypertrophy in $\mathrm{H} 9 \mathrm{c} 2$ embryonic rat cardiac cells: involvement of the phosphoinositide 3-kinase-Akt pathway. J Pharmacol Exp Therap 319, 934-940.

28. Bradford MM (1976) A rapid and sensitive method for the quantification of microgram quantities of protein, utilizing the principle of protein-dye binding. Anal Biochem 72, 248.

29. Aebi H (1984) Catalase in vitro. Methods Enzymol 105, 121-127.

30. Paoletti F, Aldinucci D, Mocali A, et al. (1986) A sensitive spectrophotometric method for the determination of superoxide dismutase activity in tissue extracts. Anal Biochem 154, 538-541.

31. Gunzler WA, Kramers H \& Flohe L (1974) An improved coupled test procedure for glutathione peroxidase. Klin Chem Klin Biochem 12, 444-448.

32. Goldberg DM \& Spooner RJ (1987) Glutathione reductase. In Methods of Enzymatic Analysis, pp. 258-265 [HV Bergmeyer, editor]. Weinheim: Verlag-Chemie.

33. Hissin PJ \& Hilf RA (1976) Fluorometric method for determination of oxidized and reduced glutathione in tissues. Anal Biochem 74, 214-226.

34. Choi EH, Chang HJ, Cho JY, et al. (2007) Cytoprotective effect of anthocyanins against doxorubicin-induced toxicity in $\mathrm{H} 9 \mathrm{c} 2$ cardiomyocytes in relation to their antioxidant activities. Food Chem Toxicol 45, 1873-1881.
35. Raghu KG \& Cherian OL (2009) Characterization of cytotoxicity induced by arsenic trioxide (a potent anti-APL drug) in rat cardiac myocytes. J Trace Elem Med Biol 23, 61-68.

36. Chomczynski P \& Sacchi N (1987) Singlet-step method of RNA isolation by acid guanidium thiocyanate-phenolchloroform extraction. Anal Biochem 162, 156-159.

37. Kimes BW \& Brandt BL (1976) Properties of a clonal muscle cell line from rat heart. Exp Cell Res 98, 367-381.

38. Watkins SJ, Borthwick GM \& Arthur HM (2011) The H9c2 cell line and primary neonatal cardiomyocyte cells show similar hypertrophic responses in vitro. In vitro Cell Dev Biol Animal 47, 125-131.

39. Hescheler J, Meyer R, Plant S, et al. (1991) Morphological, biochemical, and electrophysiological characterization of a clonal cell $(\mathrm{H} 9 \mathrm{c} 2)$ line from rat heart. Circ Res 69, 1476-1486.

40. Sipido KR \& Marban E (1991) L-type calcium channels, potassium channels, and novel nonspecific cation channels in a clonal muscle cell line derived from embryonic rat ventricle. Circ Res 69, 1487-1499.

41. Wollert KC \& Drexler H (1999) The rennin-angiotensin system and experimental heart failure. Cardiovasc Res $\mathbf{4 3}$ $838-849$.

42. Unger T (2002) The role of the renin-angiotensin system in the development of cardiovascular disease. Am J Cardiol 89 $3 \mathrm{~A}-9 \mathrm{~A}$.

43. Wang H \& Joseph JA (1999) Quantifying cellular oxidative stress by dichlorofluorescein assay using microplate reader. Free Rad Biol Med 27, 612-616.

44. Hajjar RJ \& Leopold JA (2006) Xanthine oxidase inhibition and heart failure. Circ Res 98, 169-171.

45. Poljsak B (2011) Strategies for reducing or preventing the generation of oxidative stress. Oxid Med Cell Longev 2011, 194586

46. Dinu D, Bodea GO, Ceapa CD, et al. (2011) Adapted response of the antioxidant defense system to oxidative stress induced by deoxynivalenol in Hek-293 cells. Toxicon 57, 1027-1032.

47. Devasagayam TPA, Boloor KK \& Ramasarma T (2003) Methods for estimating lipid peroxidation: an analysis of merits and demerits. Ind J Biochem Biophys 40, 300-308.

48. Nelson SK, Bose SK \& McCord JM (1994) The toxicity of high-dose superoxide dismutase suggests that superoxide can both initiate and terminate lipid peroxidation in the reperfused heart. Free Radic Biol Med 16, 195-200.

49. Shlafer M \& Shepard BM (1984) A method to reduce interference by sucrose in the detection of thiobarbituric acid-reactive substances. Anal Biochem 137, 269-276.

50. Halliwell B (1996) Oxidative stress, nutrition and health. Experimental strategies for optimization of nutritional antioxidant intake in humans. Free Radic Res 25, 57-74.

51. Peng X \& Li Y (2002) Induction of cellular glutathione linked enzymes and catalase by the unique chemo preventive agent, 3H-1,2-dithiole-3-thione in rat cardiomyocytes affords protection against oxidative cell injury. Pharmacol Res $\mathbf{4 5}$, 491-497.

52. Abhilash PA, Harikrishnan R \& Indira M (2012) Ascorbic acid supplementation causes faster restoration of reduced glutathione content in the regression of alcohol induced hepatotoxicity in male guinea pigs. Redox Rep 17, 72-79.

53. Kent KD, Harper WJ \& Bomser JA (2003) Effect of whey protein isolate on intracellular glutathione and oxidant-induced cell death in human prostate epithelial cells. Toxicol in vitro 17, 27-33.

54. Ouyang X, Takahashi K, Komatsu K, et al. (2001) Protective effect of Salvia militiorrbiza on angiotensin II induced 
hypertrophic responses in neonatal rat cardiac cells. Jpn J Pharmacol 87, 289-296.

55. Ichikawa H, Yagi H, Tanaka T, et al. (2010) Lagerstroemia speciosa extract inhibit TNF-induced activation of nuclear factor- $\kappa \beta$ in rat cardiomyocyte H9c2 cells. J Ethnopharmacol 128, 254-256.

56. Purcell NH, Tang G, Yu C, et al. (2001) Activation of NF-к $\beta$ is required for hypertrophic growth of primary rat neonatal ventricular cardiomyocytes. Proc Natl Acad Sci U S A 98, 6668-6673.

57. Li Y, Ha T, Gao X, et al. (2004) NF-кB activation is required for the development of cardiac hypertrophy in vivo. Am J Physiol Heart Circ Physiol 287, 1712-1720.

58. Baldwin AS Jr (1996) The NF-kappa B and I-kappa B proteins: new discoveries and insights. Ann Rev Immunol $\mathbf{1 4}$ 649-683

59. Jones WK, Brown M, Wilhide $\mathrm{M}$, et al. (2005) NF $\kappa \beta$ in cardiovascular disease. Cardiovasc Toxicol 5, 183-201.

60. Li RK, Li G, Mickle DA, et al. (1997) Overexpression of transforming growth factor-beta1 and insulin-like growth factor-I in patients with idiopathic hypertrophic cardiomyopathy. Circulation 96, 874-881.

61. Schultz JJ, Witt SA, Glascock BJ, et al. (2002) TGF- $\beta 1$ mediates the hypertrophic cardiomyocyte growth induced by angiotensin II. J Clin Invest 109, 787-796.

62. Yamazaki T, Yamashita N, Izumi Y, et al. (2012) The antifibrotic agent pirfenidone inhibits angiotensin II-induced cardiac hypertrophy in mice. Hypertension Res 35, 34-40.
63. Vita JA (2005) Polyphenols and cardiovascular disease: effects on endothelial and platelet function. Am J Clin Nutr 81, 292-297.

64. Ferreres F, Sousa C, Justin M, et al. (2005) Characterization of phenolic profile of Boerhaavia diffusa L. by HPLC-PAD-MS/ MS as tool for quality control. Phytochem Anal 16, 451-458.

65. Vineetha VP, Prathapan A, Soumya RS, et al. (2012) Arsenic trioxide toxicity in H9c2 myoblasts - damage to cell organelles and possible amelioration with Boerhaavia diffusa. Cardiovasc Toxicol (Epublication ahead of print version 19 November 2012)

66. Perez-Vizcaino F \& Duarte J (2010) Flavonols and cardiovascular disease. Mol Aspects Med 31, 478-494.

67. Duarte J, Jimenez R, O'Valle F, et al. (2002) Protective effects of the flavonoid quercetin in chronic nitric oxide deficient rats. J Hypertens 20, 1843-1854.

68. Calderon-Montano JM, Burgos-Moron E, Perez-Guerrero C, et al. (2011) A review on the dietary flavonoid kaempferol. Mini Rev Med Chem 11, 298-344.

69. Senthil S, Sridevi M \& Pugalendi KV (2007) Protective effect of ursolic acid against myocardial ischemia induced by isoproterenol in rats. Toxicol Mech Methods 17, 57-65.

70. Lami N, Kadota S, Kikuchi T, et al. (1991) Constituents of the roots of Boerhaavia diffusa L. III. Identification of a calcium channel antagonistic compound from the methanol extract. Chem Pharm Bull 39, 1551-1555. 